\title{
Jenis dan Jumlah Sedimen Urine Menggunakan Variasi Konsentrasi Pengawet Formalin
}

\author{
Desak Made Sri Maharani, Nurul Inayati, Maruni Wiwin \\ Jurusan Analis Kesehatan, Poltekkes Kemenkes Mataram, Indonesia \\ Email:madedesak@gmail.com
}

\begin{abstract}
Abstrak
Salah satu pemeriksaan laboratorium yang dapat digunakan untuk mendiagnosa penyakit terutama yang berkaitan dengan faal ginjal dan kelainan metabolisme tubuh yaitu pemeriksaan urinalisis. Sedimen urine adalah unsur- unsur yang tidak larut di dalam urine yang berasal dari darah, ginjal, dan saluran kemih seperti eritrosit, lekosit, sel epitel, torak, bakteri, kristal, jamur dan parasit. Formalin yang umum digunakan sebagai pengawet urine adalah formalin $40 \%$, khusus dipakai untuk mengawetkan sedimen urine penting sekali bila hendak mengadakan penilaian kuantitatif atas unsur - unsur dalam sedimen. Akan tetapi formalin yang dipasaran hanya terdapat formalin dengan konsentrasi $37 \%$ sehingga untuk pemakaian pengawet formalin perlu diturunkan konsentrasinya.Tujuan penelitian ini untuk mengetahui pengaruh variasi konsentrasi penggunaan formalin terhadap jumlah dan jenis sedimen urine Penelitian ini menggunakan rancangan penelitian pre-eksperimen dengan menggunakan 5 sampel urine yang berbeda untuk diperiksa unsur organik dan anorganik. Untuk jenis sedimen urine dianalisi secara Deskriptif sedangkan Untuk untuk jumlah dianalisi menggunkan uji One Way Annova. Hasil penelitian menunjukkan variasi konsentrasi pengawet formalin $37 \%, 30 \%, 20 \%$ dan $10 \%$ tidak berpengaruh terhadap jenis dan jumlah sedimen urine. Kesimpulan dari penelitian ini yaitu variasi konsentrasi pengawet formalin tidak berpengaruh terhadap jenis dan jumlah sedimen urine.
\end{abstract}

Kata Kunci : Formalin, Jumlah dan Jenis, Sedimen Urine

\footnotetext{
Abstract

One of the laboratory tests that can be used to diagnose diseases, especially those related to kidney physiology and abnormalities of the body's metabolism, namely urinalysis. Urine sediments are insoluble elements in urine that come from blood, kidneys and urinary tract such as erythrocytes, leukocytes, epithelial cells, thorax, bacteria, crystals, fungi and parasites. Formalin which is commonly used as a urine preservative is $40 \%$ formalin, specifically used to preserve urine
}

sediment is very important if you want to conduct a quantitative assessment of the elements in the

sediment. However, the formalin in the market only has a formalin with a concentration of $37 \%$ so that the concentration of formalin preservatives needs to be lowered. The purpose of this study was to determine the effect of variations in the concentration of formaldehyde use on the amount and type of urine sediments. different for checking organic and inorganic elements. For the type of urine sediment analyzed descriptively while for the amount analyzed using the One Way Annova test. The results showed variations in the concentration of formalin preservatives 37\%, 30\%, $20 \%$ and $10 \%$ did not affect the type and amount of urine sediment. The conclusion of this study is that variations in the concentration of formalin preservatives do not affect the type and amount of urine sediment.

Keywords : Formalin,Quantity and type, Sedimen Urine

\section{Pendahuluan}

Pemeriksaan laboratorium sangat penting dilakukan karena merupakan pemeriksaan penunjang yang dilaksanakan untuk membantu menegakkan diagnosa suatu penyakit dan menentukan prognosis yang tepat. Salah satu pemeriksaan laboratorium yang dapat digunakan untuk mendiagnosa penyakit terutama yang berkaitan dengan faal ginjal dan kelainan metabolisme tubuh yaitu pemeriksaan urinalisis (Purnomo 2007).

Seringkali sampel urine datang ke laboratorium sudah tidak segar lagi dan telah dikeluarkan beberapa jam sebelumnya. Klinisi sering mengalami kesulitan untuk tepat mengirim sampel urine sehingga hasil yang diharapkan banyak tidak sesuai dengan kondisi klinis pasien. Padahal tes urine dapat banyak memberikan informasi tentang disfungsi ginjal. Bahan tes yang terbaik adalah urine segar kurang dari 1 jam setelah dikeluarkan. Penundaan antara berkemih dan Urinalisis akan mengurangi validitas hasil, analisis harus 
dilakukan tidak lebih dari 4 jam setelah pengambilan sampel. Urine yang dibiarkan dalam waktu lama pada suhu kamar akan menyebabkan perubahan pada urine. Unsurunsur berbentuk di urine (sedimen) mulai mengalami kerusakan dalam 2 jam (Rosalita 2007).

Sedimen urine adalah unsur- unsur yang tidak larut di dalam urine yang berasal dari darah, ginjal, dan saluran kemih seperti eritrosit, lekosit, sel epitel, torak, bakteri, kristal, jamur dan parasit. Tes sedimen urine atau tes mikroskopis dipergunakan untuk mengidentifikasi unsur-unsur sedimen sehingga dipakai untuk mendeteksi kelainan ginjal dan saluran kemih, selain itu tes sedimen urine dapat juga dipakai untuk memantau perjalan penyakit ginjal dan saluran kemih setelah pengobatan (Hardjoeno, 2007).

Formalin yang umum digunakan sebagai pengawet urine adalah formalin $40 \%$, khusus dipakai untuk mengawetkan sedimen urine penting sekali bila hendak mengadakan penilaian kuantitatif atas unsur - unsur dalam sedimen. Akan tetapi formalin yang dipasaran hanya terdapat formalin dengan konsentrasi $37 \%$ sehingga untuk pemakaian pengawet formalin perlu diturunkan konsentrasinya. Pemakaian formalin yang berlebihan dapat mempengaruhi hasil pemeriksaan urine terhadap jenis dan jumlah sedimen urine oleh sebab itu perlu dilakukan penelitian untuk mencari konsentrasi pengawet formalin yang baik dan tidak berpengaruh terhadap hasil pemeriksaan sedimen urine.(Gandasoebrata 2013)

\section{Rancangan Penelitian}

Penelitian ini bersifat pre-eksperiment merupakan rancangan penelitian yang belum dikategorikan sebagai eksperimen sungguhan. Hal tersebut karena pada rancangan ini belum dilakukan pengambilan sampel secara acak atau random serta tidak dilakukann control yang cukup terhadap variabel pengganggu yang dapat mempengaruhi variabel terikat.

Rancangan penelitian yang digunakan adalah Rancangan Acak Lengkap. Dalam penelitian ini, peneliti Ingin mengetahui Jenis dan Jumlah Sedimen Urine Menggunakan Variasi Konsentrasi Pengawet Formalin dengan menggunakan 5 perlakuan yaitu :

T0 = Urine Segar sebagai kontrol

$\mathrm{T} 1=$ Penambahan Formalin dengan konsentrasi $37 \%$ kedalam urine segar

$\mathrm{T} 2=$ Penambahan Formalin dengan konsentrasi $30 \%$ kedalam urine segar

$\mathrm{T} 3=$ Penambahan Formalin dengan konsentrasi 20\% kedalam urine segar

$\mathrm{T} 4=$ Penambahan Formalin dengan konsentrasi $10 \%$ kedalam urine segar

Dalam penelitian ini juga dilakukan pengulangan atau replikasi untuk memperoleh dan menambah ketepatan hasil eksperimen. Besar sample yang digunakan dalam penelitian ini yaitu sebanyak 5 sample.

Teknik Pengambilan Sampel

Teknik pengambilan sampel dilakukan dengan teknik Porposive Sampling yaitu pengambilan sample didasarkan pada suatu pertimbangan tertentu yang dibuat oleh peneliti itu sendiri, berdasarkan ciri atau sifat sifat populasi yang sudah diketahui sebelumnya. (Notoadmodjo.S 2010).

Adapun kreteria urine yang digunakan adalah urine yang segar dengan sampel urine yang patologis seperti orang DM atau ISK.

\section{Analisis Data}

Untuk jenis dan jumlah sedimen urine dianalisi secara Deskriptif analitis yaitu analisa dengan melakukan evaluasi terhadap kebenaran data yang dipakai maupun sebagai masukan untuk analisa kebijakan atau melakukan intervensi terhadap sampel berupa eksperimen. (Sugiyono 2004)

\section{Hasil Penelitian}

Data hasil penelitian jenis dan jumlah sedimen urine sebelum diberikan formalin dan setelah diberi formalin 10\%, 20\%, 30\% dan $37 \%$. Adapun hasil pemeriksaan Sedimen urine yang menggunakan 5 sampel dapat dilihat pada tabel 
Tabel 1

Hasil pemeriksaan Jenis dan jumlah Sedimen Urine

\begin{tabular}{|c|c|c|c|c|c|c|}
\hline \multirow[t]{2}{*}{ Sampel } & \multirow[t]{2}{*}{ Jenis Sedimen } & \multicolumn{5}{|c|}{ Perlakuan } \\
\hline & & T0 & T1 & T2 & T3 & T4 \\
\hline 1 & Leukosit & $>30$ & $15-20$ & $15-20$ & $15-20$ & $15-20$ \\
\hline & Eritrosit & $1-5$ & $1-5$ & $1-5$ & $1-5$ & $1-5$ \\
\hline & Epitel & $5-10$ & $5-10$ & $5-10$ & $5-10$ & $5-10$ \\
\hline 2 & Leukosit & $10-20$ & $10-18$ & $10-18$ & $10-18$ & $10-18$ \\
\hline & Eritrosit & $0-3$ & $0-3$ & $0-3$ & $0-3$ & $0-3$ \\
\hline & Epitel & $5-10$ & $5-10$ & $5-10$ & $5-10$ & $5-10$ \\
\hline 3 & Leukosit & $20-25$ & $15-20$ & $15-20$ & $15-20$ & $15-20$ \\
\hline & Eritrosit & $0-3$ & $0-3$ & $0-3$ & $0-3$ & $0-3$ \\
\hline & Epitel & $10-20$ & $10-20$ & $10-20$ & $10-20$ & $10-20$ \\
\hline 4 & Leukosit & $20-25$ & $15-20$ & $15-20$ & $15-20$ & $15-20$ \\
\hline & Eritrosit & $0-5$ & $0-5$ & $0-5$ & $0-5$ & $0-5$ \\
\hline & Epitel & $10-15$ & $10-15$ & $10-15$ & $10-15$ & $10-15$ \\
\hline 5 & Leukosit & $15-20$ & $10-20$ & $10-20$ & $10-20$ & $10-20$ \\
\hline & Eritrosit & $0-3$ & $0-3$ & $0-3$ & $0-3$ & $0-3$ \\
\hline & Epitel & $5-10$ & $5-10$ & $5-10$ & $5-10$ & $5-10$ \\
\hline Total & Leukosit & 120 & 98 & 98 & 98 & 98 \\
\hline & Eritrosit & 19 & 19 & 19 & 19 & 19 \\
\hline & Epitel & 65 & 65 & 65 & 65 & 65 \\
\hline Rerata & Leukosit & 24 & 20 & 20 & 20 & 20 \\
\hline & Eritrosit & 4 & 4 & 4 & 4 & 4 \\
\hline & Epitel & 13 & 13 & 13 & 13 & 13 \\
\hline
\end{tabular}

Ket :

T0 : Sebelum diberi formalin

T1 : Setelah diberi formalin $37 \%$

$\mathrm{T} 2 \quad$ : Setelah diberi formalin $30 \%$

T3 : Setelah diberi formalin $20 \%$

T4 : Setelah diberi formalin $10 \%$

$1-5 \quad$ : Sampel urine

Tabel 4.1 menunjukkan bawa hasil penelitian yang telah dilakukan pada pengawet formalin konsentrasi 37\%, 30\%, 20\% dan 10\% diketahui tidak terdapat perbedaan jenis sedimen urine dan jumlah yang tidak berkurang dari sebelumnya. Adapun rata rata dari masing masing sampel yaitu tanpa formalin Lekosit 24, Eritrosit 4, dan Epitel 13, sampel dengan formalin $37 \%$ Lekosit 20, Eritrosit 4, dan Epitel 13, sampel dengan formalin $30 \%$ Lekosit 20, Eritrosit 4, dan Epitel 13, sampel dengan formalin $20 \%$ Lekosit 20, Eritrosit 4, dan Epitel 13 dan sampel dengan formalin $10 \%$ Lekosit 20, Eritrosit 4, dan Epitel 13.

\section{Pembahasan}

Sedimen urinee adalah unsur- unsur yang tidak larut di dalam urinee yang berasal dari darah, ginjal, dan saluran kemih seperti eritrosit, lekosit, sel epitel, torak, bakteri, kristal, jamur dan parasit. Untuk pemeriksaan sedimen urinee dengan penundaan perlu diberi pengawet agar tidak membuat hasil menjadi negative palsu. Pengawet yang umum digunakan sebagai pengawet urinee adalah formalin 40\%, khusus dipakai untuk mengawetkan sedimen urinee penting sekali bila hendak mengadakan penilaian kuantitatif atas unsur - unsur dalam sedimen. Akan tetapi formalin yang dipasaran hanya terdapat formalin dengan konsentrasi 37\% sehingga untuk pemakaian pengawet formalin perlu diturunkan konsentrasinya. Pemakaian formalin yang berlebihan dapat mempengaruhi 
hasil pemeriksaan urinee terhadap jenis dan jumlah sedimen urinee.

Tes sedimen urinee (mikroskopik) digunakan untuk mengidentifikasi jenis atau unsur sedimen urinee, yaitu eritrosit, leukosit, dan sel epitel,. Untuk pemeriksaan sedimen urinee dibutuhkan urinee sewaktu yang masih segar dalam penampungan yang tertutup rapat dan tidak terkontaminasi. Pemeriksaan harus dilakukan secepat mungkin, paling lambat 1 jam setelah urine ditampung. Melakukan penundaan pemeriksaan dapat menjadi sumber kesalahan, sehingga hasil yang diharapkan tidak sesuai denga kondisi klinis pasien. Unsur-unsur berbentuk (sedimen) dalam urinee mulai rusak dalam waktu 2 jam dan bila dibiarkan lama dalam suhu kamar tanpa diberi pengawet akan terjadi lisis sel serta torak dan urinee akan berubah menjadi alkalis.

Berdasarkan hasil peneitian yang menunjukkan pemeriksaan sedimen urinee segar tanpa pemberian pengawet formalin menunjukkan rerata hasil jenis dan jumlah sedimen urinee yaitu leukosit 24 , eritrosit 4 dan epitel 13, pemeriksaan sedimen urinee segar dengan pemberian pengawet formalin $10 \%$ menunjukkan hasil jenis dan jumlah sedimen urinee yaitu leukosit 20, eritrosit 4 dan epitel 13, pemeriksaan sedimen urinee segar dengan pemberian pengawet formalin $20 \%$ menunjukkan hasil jenis dan jumlah sedimen urinee yaitu leukosit 20 , eritrosit 4 dan epitel 13, pemeriksaan sedimen urinee segar dengan pemberian pengawet formalin $30 \%$ menunjukkan hasil jenis dan jumlah sedimen urinee yaitu leukosit 20, eritrosit 4 dan epitel 13 dan pemeriksaan sedimen urinee dengan pemberian pengawet formalin $37 \%$ menunjukkan hasil jenis dan jumlah sedimen urinee yaitu leukosit 20, eritrosit 5 dan epitel 13.

Hasil penelitian yang telah dilakukan berdasarkan pemeriksaan mikroskopis urinee yang dilakukan diketahui bahwa hasil yang diperoleh jika pemeriksaan sedimen urinee yang diberikan pengawet formalin dengan konsentrasi 10\%, 20\%, 30\% dan $37 \%$ kemudian ditunda selama 2 jam menunjukkan hasil yang tidak jauh berbeda dengan pemeriksaan sedimen urinee tanpa diberikan pengawet formalin. Dalam menggunakan pengawet pemeriksaan sedimen urinee dapat menggunakan konsentrasi formalin $10 \%$ dimana pada hasil penelitian menunjukkan tidak mempengaruhi hasil pemeriksaan sedimen urinee. Sehingga dengan ataupun tanpa di berikan pengawet formalin tidak mempengaruhi hasil pemeriksaan sedimen urinee.

Penelitian ini dilakukan dengan menghitung jenis dan jumlah sedimen urinee sebelum diberi konsentrasi formalin dan setelah diberi konsentrasi formalin dan ditunda selama 2 jam pemeriksaan 5 sampel urinee yang mengandung leukosit ini mengalami penurunan jumlah leukosit, dimana disebabkan karena lamanya penyimpanan, dimana penurunan jumlah leukosit akibat lamanya penyimpanan urinee ini didukung oleh penelitian (Supardi 1985) yang menyatakan bahwa lama waktu penyimpanan saat menunggu pemeriksaan menyebabkan menurunnya jumlah leukosit yang dikandung didalamnya sebanyak $15 \%$ setiap jam penyimpanan. Leukosit dalam urinee akan mengalami otolisis sejalan dengan satuan waktu. Dimana dalam penelitian sebelumnya juga menyatakan terdapat pengaruh yang bermakna lama penyimpanan urinee pada suhu kamar terhadap jumlah leukosit pada penderita diabetes melitus. (Kustiningsih et al 2008).

Menurut penelitian sebelumnya disimpulkan bahwa tes sedimen urine leukosit, eritrosit dengan metode Shih-Yung dan sel epitel berdasarkan CCLS dengan melakukan penundaan waktu pemeriksaan 2 jam dan 3 jam, masih dalam batas normal adanya leukosit, eritrosit, dan sel epitel dalam urine dan tidak terdapat pengaruh yang signifikan terhadap hasil pemeriksaan sedimen urine leukosit, eritrosit dan sel epitel pada pemeriksaan segera, tunda 2 jam, dan 3 jam. (Naid, et al 2014)

Sehingga dalam menggunakan pengawet formalin untuk pemeriksaan sedimen urinee yang dilakukan penundaan dapat disarankan menggunkan konsentrasi yang lebih kecil yaitu 10\% karena tidak mempengaruhi hasil yang signifikan terhadap jumlah dan jenis sedimen urine.

\section{Kesimpulan}

Sedimen urine segar tanpa pengawet formalin sebanyak leukosit 24 , eritrosit 4 dan epitel 13. Sedimen urine segar dengan pengawet formalin 37\% sebanyak leukosit 20, eritrosit 4 dan epitel 13. Sedimen urine segar dengan pengawet formalin $30 \%$ sebanyak leukosit 20, eritrosit 4 dan epitel 13. Sedimen urine segar dengan pengawet formalin $20 \%$ sebanyak leukosit 20, eritrosit 4 dan epitel 13. 
Sedimen urine segar dengan pengawet formalin $10 \%$ sebanyak leukosit 20 , eritrosit 4 dan epitel 13.Jenis dan Jumlah sedimen urine menggunakan variasi konsentrasi pengawet formalin $10 \%, 20 \%, 30<$ dan $37 \%$ tidak terdapat perbedaan.

\section{Daftar Pustaka}

Albertus Agung Mahod. 2004. In Pedoman Teknik Dasar Untuk Laboratorium Kesehatan, Jakarta: Penerbit Buku Kedokteran ECG.

Astawan, Made. 2006. Mengenal Formalin Dan Bahayanya. Jakarta: Penebar swadaya.

Dradjat Nendrosuwito. 2004. "Good Laboratory Practice." In ed. Dapartemen Keseatan Republik Indonesia. Jakarta.

EC Pearch. 2005. "Anatomi Dan Fisiologis Untuk Paramedis." In Anatomi Dan Fisiologis Untuk Paramedis, Jakarta: PT. Gramedia Pustaka Utama.

Evelyn dan Pearce. 2009. In Anatomi Dan Fisiologi Untuk Paramedis, Jakarta: Gramedia.

Gandasoebrata, R. 2006. Penuntun Laboratorium Klinik. Jakarta: Dian Rakyat.

Gandasoebrata. 2013. Penuntun Laboratrium Klinik. Jakarta: Dian Rakyat.

Guyton. 1995. In Fisiologi Manusia Dan Mekanisme Penyakit (Human Physiology and Mechanisms of Disease), Jakarta: Buku Kedokteran EGC.

Hardjoeno, dan Fitriani. 2007. Substansi Dan Cairan Tubuh. Lembaga Penerbitan Universitas Hasanuddin.

Hardjoeno, H dan Fitriani. 2007. "Substansi Dan Cairan Tubuh." (Lembaga penerbit Universitas Hasanuddin. Makasar.).

Iqbal Ali. 2008. "Urinalisis (Analisis Kemih)."

http://iqbalali.com/2008/02/10/urin alisis-analisis-kemih/ (March 15, 2019).

Klatt E. 2017. "Microscopic Urinalysis." http://wwwmedlib.ed.utah.edu/webpath/tutorial /urine (January 6, 2019).
Kustiningsih, Yayuk, Jujuk Anton Cahyono, and Nur Rahmiat. 2008. "No Title." Pengaruh Lama Penyimpanan Urine Pada Suhu Kamar Terhadap Jumlah Leukosit Studi Pada Penderita Diabetes Melitus: Jurusan Analis Kesehatan Poltekkes Kemenkes Banjar.

Lestari, E. 2011. Pedoman Teknik Dasar Untuk Laboratorium Kesehatan. Edisi ke 2. Jakarta: World Health Organization.

Maria Tuntun, Wieke Sriwulan, Doni Setiawan, Anik Nuryati. 2018. Kendali Mutu Teknologi Laboratorium Medik. ed. Agustus 2018 Cetakan pertama. Kementrian Kesehatan Republik Indonesia.

Notoadmodjo.S. 2010. Metodologi Penelitian Kesehatan. Jakarta: PT Rineka Cipta.

Priyana. 2010. Patologi Klinik Untuk Kurikulum Pendidikan Dokter Indonesia. Cetakan ke. Jakarta: Universitas Trisakti.

Purnomo. 2007. Dasar - Dasar Urologi. Jakarta: Informedika.

Rosalita, L. 2007. "Pengaruh Penundaan Waktu Terhadap Hasil Urinalisis." Universitas Islam Indonesia.

Soebrata, G. 2007. Penuntun Laboratorium Klinik. ed. Dian Rakyat. Jakarta.

Speroni. 2012. "Urinalysis Results Interpretation."

Sudiono H. 2006. Urinalisis. Jakarta: Fakultas Kedokteran Universitas Kristen Krida Wacana (UKRIDA).Jakarta.

Sudoyo. 2006." In Infeksi Saluran Kemih, Jakarta: Ikatan Dokter Indonesia.

Sugiyono. 2004. In Statistika Untuk Penelitian., Bandung.

Suksesi Anggraini. 2016.In Kimia Klinik, Jakarta: Ikatan Dokter Indonesia.

Supardi. 1985. In Cara Sederhana Untuk Diagnosa Bakteri Urine., Bandung: Alumni.

Syaifuddin. 2006." In Anatomi Fisiologi Untuk Mahasiswa Keperawatan, ed. edisi ke 3. Jakarta: EGC.

Tadjuddin Naid, Fitriani Mangerangi, Hanifah Almahdaly. 2014. "AsSyifaa." Pengaruh 
Penundaanwaktu Terhadap Hasil

Urinalisis Sedimen Urin Vol 06 (02: Fakultas Farmasi Universitas Hasanuddin Makassar.

Widyastuti, Nur Vita Purwaningsih dan Rahma. 2018. Perbandingan Pemeriksaan Leukosit Urine Segar Dengan Setelah 2 Jam Di Suhu Kamar (Universitas Muhammadiyah Surabaya).

Wirawan R. 2016. Penilaian Hasil Pemeriksaan Urine. Jakarta: Cermin Dunia Kedokteran FKUI. 